\title{
The study of association between the companies market value and the oil and gas reserve value.
}

\author{
Bazhar A Abdulrahman Kawani , Kahi Ilham Abdal
}

Technical Finance and Accounting Dep. Erbil Polytechnic University Kurdistan Region - Iraq

\begin{abstract}
This research investigates the relationship between oil and gas reserves value and oil and gas company's market value by using samples of oil and gas companies which internationally base from 2007 to 2011 . Additionally, in order to find the overall relationship between oil and gas reserves and the company's market value, this research has found the average value of oil and gas reserves in the year and then used the calculated market value which has been calculated by the researcher (cohort study). To find the individual association between oil and gas reserves value and oil and gas market value, this research has found the correlation by using excel spreadsheet and used the annual amount of oil and gas reserves then multiplied by annual averages of oil and gas prices (panel study). Additionally, in order to find the relationship between oil and gas reserves and company's market value, this research has found the allocated companies' market value. The overall result of this research shows there is a positive relationship between oil and gas reserves value and oil and gas company's market value. Besides, for the individual relationship between oil and reserves value and oil and gas company's market value, the result was different from company to company and the difference can be there depending on the company reserves amount, companies' strategies toward reserves disclosure and the company size.
\end{abstract}

\section{Introduction}

Oil and gas industry is considered as an important sector because it is associated with a countries economy. There are many ways to disclose oil and gas reserve, but the Financial Accounting Standard Board and Securities Exchange And commission have put a standard in order to make the comparison between oil and gas companies easier. The market value of companies will be affected by different factors such as economic conditions and news about the companies (Oilandgasiq, 2013). These aspects give the importance of disclosing the oil and gas reserve value of companies because it might affect the companies market value positively or negatively, which will possibly affect their investors. The aim of this research is to examine whether oil and gas reserve value can be used on the balance sheet as an asset in order to explore the relationship between oil and gas companies reserve and their market value. If the oil and gas reserves used as an asset then it will affect their market value and vice versa. The outline of this research will be as follows, first section reserve and types of reserve. Second section, the disclosure requirements of reserve in oil and gas companies. Third section, market value. Next, the factors affecting market value. Then, methodology, methods, data collection and description section. After that, results and discussion section. Finally, the personal reflection on the research methods module section.

\section{Oil and gas reserves:}

Oil and gas companies should consider that oil and gas reserves are an important item in companies reports because the users of reserve information depend on the provided information that companies disclose in their annual reports for their decision-making (SPE, 2007). According to the Society of Petroleum Evaluation Engineers (SPEE) (Cited in ASC, 2007: online) 'Reserves are estimated remaining quantities of oil and natural gas and related substances anticipated to be recoverable from known accumulations, as of a given date, based on the analysis of drilling, geological, geophysical, and engineering data; the use of established technology; and specified economic conditions, which are generally accepted as being reasonable. Reserves are further classified according to the level of certainty associated with the estimates 
and may be sub-classified based on development and production status'. Additionally, oil and gas reserves have been divided into three categories, which have different percentages of certainty such as, proved reserves, probable reserve and possible reserve (SPEE, 2007). Firstly, proved reserve is the reserve that has a high certainty of being recoverable by the oil and gas companies which is an estimation of producing this kind of reserve has $90 \%$ of certainty, it can be used for commercial purpose because the investors might rely on these reserves for making decisions. Additionally, proved reserved estimation will support investors for knowing the certainty of their investment on the field that being classified as a developed or undeveloped field because the recoverable amount of the developed field is higher than the undeveloped, and it could become a product in the short time by using companies current equipments (SEC, 2008). Secondly, probable reserve has less certainty than proved reserves and the estimated quantities of probable reserves has a $50 \%$ chance to become recoverable. As a proved reserve it could be used in commercial issues because it has been estimated by engineering and Geoscience separately from the proved reserve which a user of reserve information can consider this type of reserve when they are making decisions (SPE, 2007). Finally, there is another reserve that companies might use for estimating the quantities of oil and gas reserves which is known as possible reserves. In addition, it cannot be used for commercial issues and the possibility of being recoverable by companies is less than $10 \%$ and the chance of producing this type of reserve, related to the technology and economic conditions because companies might not be capable of recovering the estimated amount of the reserve in the current situation by the current equipment's (SPE, 2007).

\section{The disclosure requirement for oil and gas companies reserve:}

There are many issues that oil and gas companies should take into account in order to disclose information of oil and gas reserves. Additionally, different organization have been issued standards that require oil and gas companies the methods of the disclose reserves such as Financial Accounting Standard Board (FASB), The Society of Petroleum Engineers (SPE) and Securities and Exchange Commission (SEC). First of all, the net quantities of the oil and gas that should be disclosed is the most important point, as well as the change that might happen in the reserve quantities from the beginning and by the end of the year. In addition, information on the proved undeveloped and proved developed reserves has to be disclosed separately for giving more explanation about the reserve quantities, whereas it is the companies choose to disclose the probable and possible reserves in their reports (SEC, 2009). The data that is given in the annual report should be updated and include all changes that happened in the reserve quantities, as well as the ability of the companies related to the technology for producing the reserve in the future. Moreover, the information that is required should include new fields which have been explored and contain oil and gas reserves, plus the quantities of the reserve that companies buy or sell to each other. Secondly, the area of the reserves have become an important aspect of disclosing oil and gas reserve because it may affect the reserve information users' decision. Disclosing different reserve geographic areas should be considered, in order to give a clear idea to the user of reserve information (SPE, 2001). Thirdly, oil and gas reserves should be disclosed by the standard measurement that is used by companies which are barrels and cubic feet and the Net Present Value of Future Net Revenue should be calculated for the amount of reserve considering the cost and the discount rate which requires being $10 \%$ of the reserves value (SPE, 2001). The certainty of the reserve that companies disclose is another requirement which companies should take into account because it might have an economic value and can be used for commercial purpose such as selling and buying. Next, companies should not disclose uncertain figures and amounts of reserve under governments pressures, even the name of the area should not be mentioned in the companies annual reports. Finally, the estimator or Reserves Audits should be disclosed for making the reserve amount reliable which has been to be done by an internal estimator or external estimator and the qualification of the reserve estimator should be taken into account because it will show to the investor's whether the figure and the amount reflect the expectation of the companies reserve or if it is used as a tool for attracting investors (SEC, 2009). However, opponent believes that the reserve information cannot be used as a high safe data because it can be risky in relation to company accessibility for recovering the reserve, the technology changes, as well as the political issues such as tax, environmental standard changes and government changes (Cooper et all, 1979). 


\section{Companies market value:}

"What investors believe a firm is worth; calculated by multiplying the number of shares outstanding by the current market price of a firm's shares." (Harvey, 2012: online). Market value is important for accounting and law purpose. In the Past, it is used to determine the market value of assets. For example market value of assets after depreciation. This is considered to be significant for determining the amount of tax which the companies should pay for government. In the latter, market value has used to assess companies damage in a lawsuit (Harvey, 2012). Investors are interested in knowing the market value in order to compare it with book value or net asset or using another measure to find out whether the company is adequate in value or undervalued or overvalued (Investopedia, 2013).

\subsection{Factors affect market value:}

There are many factors which affect company market value. First, internal developments will affect the share price positively such as merger and acquisition, earnings reports and dividend suspension. Secondly, world events will affect the share price negatively such as war, civil unrest. Thirdly, inflation and interest rate will affect the share price. when interest rate increases many investors sell their share stocks at higher risk with government-backed - securities to get the benefit of high-interest rate with more protected investment. Next, the exchange rate will have a direct impact on market share price for companies which are trading in foreign countries. Long term exchange rate component, with fundamental market supply and demand while short term movement of exchange rate associated with news, events of future trading which is difficult to predict. In addition, there are other factors which affect market value such as economic conditions, market perception and news, the impact of these factors will depend on the type of information or conditions whether it positive or negative. If it is positive it will raise the share price, whereas negative factors will lead to decreasing in share price (Wolski and Media, 2007; Anderson and Media, 2013).

There are many studies which have been done before on the reserve. Firstly, Oil price and reserve location-Effects on oil and gas sector returns which have been done by Kretzschmar and Kirchner (2009) through their research, they provide evidence about the effect of the oil and gas reserve in the oil and gas companies. In addition, they found that oil and gas companies have affected directly and negatively by exposures to reserve location (Kretzschmar and Kirchner, 2009). Secondly, there is a research about Oil and gas reserve value disclosures and bid-ask spreads which have been done by Boone (1998) and came up with empirical evidence which suggest that the initial disclosure of the discounted present value of oil and gas reserves, mandated by the United States Securities and Exchange Commission (SEC) in Accounting Series Release No.253 (ASR 253) was associated with a decline in the bid-ask spread of disclosing firm common stock that appears to have persisted for the twelve month period following the initial reserve disclosures. The first research is similar to this research on the basis of reserve and its relation to the oil and gas companies return, but it differs with this research because it found the association between oil and gas prices and reserve location. Additionally, the second research is similar to this research because it considered the value of the reserve which consider is a main variable of this research, but it differs with the second research because second research focus more on the disclosure issues related to reserve, while this research focus on the relationship between oil and gas reserve and market value of oil and gas companies.

\section{Research Methodology and Data collection}

The philosophy of this research is an epistemological approach based on inductive reasoning and relate to positivism perspective. This research is considered as quantitative research, depending on the numerical number to explain the relationship between these variables. In addition, this approach starts with specific observations, which are ten oil and gas companies over 5 years. Then it moves into pattern identified in this research of oil and gas reserve and its relationship with these companies market value. Then it moves to tentative hypothesis and examines the relation. Next, collect the primary and secondary data for analysis purpose. Finally, come up with a theory which would be a grounded theory (Bryman and Bell, 2011; Thomas, 2003). This approach starts with specific observation and then moves into a broader theory (Burney, 2008). The importance of the inductive approach derived from the fact that there is not any 
research which has been done until now to explore the relationship between reserve value and market value of oil and gas companies. As a result, the theory of this research is considered as an original outcome.

\subsection{Qualitative Data:}

This research will depend on both Qualitative \& Quantitative data. Qualitative data based on information that include opinion, attitude which consider peoples thoughts and how they feel such as case studies, unstructured interview, unstructured observations. Besides, qualitative data this can be considered as descriptive data and hard to analyse (McLeod, 2008; Insite, 2007). In addition, the qualitative data considered to be significant for this research in order to get a manager attitude towards the reserve value and get a deep understanding of the relationship between reserve value and market value. Qualitative data can be collected from BP, BHP Billiton, Chevron, ConocoPhillips, Dana Petroleum, ExxonMobil, Lundin Petroleum, Tullow Oil, Statoil and Shell annual report in order to analyse different attitude.

\subsection{Quantitative Data:}

There is a need for quantitative data in order to analyse the relationship between reserve value and market value. Quantitative data is the information in the form of numerical data which has been gathered to measure and analyse aspects of different variable. This data can be measured by using units or can be put into categories and rank them (Bryman and Bell, 2011; McLeod, 2008). This research quantitative data is the amount of reserve in monetary term of oil and gas for BP, BHP Billiton, Chevron, ConocoPhillips, Dana Petroleum, ExxonMobil, Lundin Petroleum, Tullow Oil, Statoil and Shell, and this can be collected from these companies annual reports and the annual average oil and gas prices. This research has used an annual average of oil and gas prices which was prepared by OPEC organisation. In addition, in order to find out the required relationship for this research, there is a need for finding the share price and number of shares of each company to find the market value. Besides, information about the number of shares have been found in the annual report. Information about share price have also been found on the company websites, yahoo finance website in order to get the share price.

\subsection{Data description \& collection:}

This research depends on different types of data such as primary data and secondary data. The primary data which has been calculated by research such as the market value of BP, BHP Billiton, Chevron, ConocoPhillips, Dana Petroleum, ExxonMobil, Lundin Petroleum, Tullow Oil, Statoil and Shell and the information about share price and the number of shares as found in the annual report, company websites, yahoo finance websites. Additionally, this information is trusted information because It is publicly available and has been revised by external and internal auditors, about Yahoo finance and financial times. Also, these were considered as a trusted information source because this information has been done by analysts people. Moreover, the value of the reserve that founded by researcher by using the amount of reserve proved reserves and then this research have found the average of this reserve and multiplied it by the annual average oil and gas prices, which have been prepared by OPEC organization. Besides, possible and probable reserve was not taken into account for this research, because it is an optional requirement for companies. That means some companies have these types while others have not disclosed it. Another reason for ignoring these types of reserve is that their estimation of probable and possible recovery are low 10\%, 50\% respectively. The information of OPEC organization is trusted because it has been found by expert people. These research observation companies are internationally based. The design of this research depends on a longitudinal research design with panel study. Panel study was used in this research in order to find out the correlation between reserve value and market value in each company was for 5 years. This design is important to find out the impact of social changes and notice the improvement with identifying the influence causal factor (Bryman and Bell, 2011). Moreover, this research has used cohort study to find out the overall relationship between the reserve value of oil and gas companies and their market value. The cohort study was found by finding the averages of oil and gas reserve for all ten companies depending on year basis. The correlation tool has been used by using excel spreadsheet in order to find the relationship between reserve value and market value. This tool has been used because of the experience of the researcher and it is easier than other tools which has saved time. Moreover, it gives the same result of the regression linear. 


\section{Result \& discussion:}

After examining these companies BP, BHP Billiton, Exxon Mobil, Tullow, Statoil, Nexen, Shell, Lundin, Chevron and Marathon, the overall relationship between oil reserve and the market has found it to be $46 \%$ (see appendix 1). This percentage shows that there is a positive relationship between oil and gas reserves with market value of these companies on the basis of the year. This means that the researcher found the averages of oil and gas reserves of these ten companies depending on the year such as 2007 and after that also did it for another four years, and then the correlation between these oil and gas reserves have been found with the market value of these companies. The positive association means that oil and gas companies should use the value of these reserves as an asset on the balance sheet because it has a positive impact on the market value. With increasing oil and gas reserves the market value of oil and gas companies will increase. However, with decreasing the oil and gas reserves the market value of companies will decrease. Additionally, after examining the individual companies oil and gas reserves with their market value, the variety of results and percentages were found. The researcher has categorized his findings into four groups. First, companies with negative association which are BP and BHP Billiton (see appendix 2). These companies have low negative percentages $-12 \%$ for BP and $-11 \%$ for BHP Billiton; these low associations may exist because of the amount of oil and gas reserves in the fluctuate process (increases, decrease) depending on the companies strategies. Another reason fr this low percentage can be the oil and gas prices (instability of oil and gas prices depending on the many factors, political and economic). Additionally, these companies do not consider the reserves value as an asset and they have a strategy of keeping a low level of oil and gas reserves or maybe the market value has increased or decreased due to bad news of these companies which probably affected their share price on the market. A second group with $60 \%-62 \%$ associations includes two companies which are Shell and Lundin with $66 \%$ and $62 \%$ respectively (see appendix 3). These percentages indicate that these companies reserve value have a medium impact on the oil and gas companies market value. This can be explained by the amount of reserves that keep the company and these different percentages can exist because of every companies have different strategies towards disclosing the amount of reserves. Moreover, these companies do keep the appropriate level of reserves but not consider it as an important asset and this will probably affect their attitude towards oil and gas reserves disclosure. A third group with percentages between $80 \%-85 \%$, this group consists of two companies which are Chevron and Marathon with $80 \%$ and $85 \%$ respectively (see appendix 2). This percentage indicates that these companies have a high amount of oil and gas reserves. This could be due to their strategies towards disclosing and keeping a high level of reserves, also due to their size and location. Besides, the high association between oil and gas reserve value and market value might change companies attitudes or strategies to disclose their oil and gas reserves as an important asset on the balance sheet to attract more investors. Fourth group and the final one, with higher percentages. This group consists of four big sized companies which are Exxon Mobil, Tullow, Statoil and Nexen with 91\%, 93\%, 95\%, 96\% (see appendix 3 and 4). These high percentages indicate that these companies reserve of oil and gas amounts are very high, which means they consider the reserves of oil and gas as an important asset of the company, which may affect their decision to disclose it on the balance sheet with an asset. These high percentages show the strong relationship between these companies oil and gas reserves value and their market value. These companies keep a high amount of oil and gas reserves. After identifying the overall relationship between oil and gas reserves value, market value and identifying and explaining the individual companies result. Oil and gas companies should disclose the oil and gas reserves as an asset on the balance sheet due to positive and high association of oil and gas reserves value and their market value of the eight companies result out of ten companies illustrates this. This research result will be significant for both companies and investors (existing shareholders and potential). Companies will consider the importance of the research result and may change their attitude towards disclosing oil and gas reserves as an asset on the balance sheet because of these high associations and because companies who objectives are increasing their market value and keeping the shareholders happy and satisfied. On the other hand, Shareholders of oil and gas companies will get benefit from the research results because they identify other important factors, which affect their share price in the market, and they will consider it in their decision. This result will be also important for potential shareholders because it will help them when choosing the sector which will get high returns. 


\section{Conclusion}

After examining ten oil and gas companies, the relationship between oil and gas reserves value and market value has been found as follows; there is an overall positive relationship between oil and gas reserves value and market value. The researcher has found a variety of results when the individual companies have examined, and it has divided it into four groups. First group with negative percentage. This group includes two companies which are BP and BHP Billiton. The second group averages are between $60 \%-62 \%$ which include Shell and Lundin. The third group averages between $80 \%-85 \%$ and includes Chevron and Marathon. The final and fourth group averages are $91 \%, 93 \%, 95 \%$ and $96 \%$ and this group includes Exxon Mobil, Tullow, Statoil and Nexen. The reasons behind these differences have been discussed in detail in the result and discussion part and this was due to different factors the amount of the oil and gas reserves, the companies size and the companies attitude in towards reserves disclosure. The result of this research is important for both investors and companies.

\section{Reference}

[1] Anderson, A., and Media, D., 2013. Three Factors That Affect the Market Value of a Stock [online]. United state, Houston Chronicle Available at: http://smallbusiness.chron.com/three-factors-affectmarket-value-stock-4120.html.

[2] AQIL BURNEY.M.S., 2008. INDUCTIVE \& DEDUCTIVE RESEARCH APPROACH [online]. University of Karachi. Available at : http://www.scribd.com/doc/13920229/Inductive-DeductiveResearch-Approach-060320081.

[3] ASC, 2007. DEFINITIONS OF OIL AND GAS RESOURCES AND RESERVES [online]. Canada, SPEE. Available

http://www.albertasecurities.com/Search/Results.aspx?k=Reserves\%20are\%20estimated\%20remaini ng\%20quantities .

[4] BHP Billiton PLC, 2013. Annual report ended at 31rd June 2007-2011 [online]. United Kingdom: BHP Billiton PLC Available at: http://www.bhpbilliton.com/home/investors/reports/Pages/default.aspx .

[5] bid-ask spreads [Online]. USA, Mississippi State University. Journal of Accounting and Public Policy 17 (1998) 55-84. Available at: http://www.econbiz.de/en/search/detailed-view/doc/all/oil-andgas-reserve-value-disclosures-and-bid-ask-spreads-boone/10006918998/?no_cache $=1$

[6] Boone, P. J., 1998. Oil and gas reserve value disclosures and

[7] BP PLC, 2013. Annual report ended at 31rd December 2007-2011 [online]. United Kingdom: BP PLC. http://www.bp.com/sectionbodycopy.do? categoryId=9039423\&contentId=7072266\&nicam=vanity . [Accessed on 28 January 2013].

[8] BRYMAN, A., and BELL, E. 2011. Business Research Methods (3rd Ed), Oxford: Oxford University Press.

[9] Chevron Corporation, 2013. Annual report ended at 31rd December 2007-2011 [online]. United Kingdom: Chevron Corporation . Available at: http://www.chevron.com/annualreport/2011/.

[10] Cooper, K., and Flory, M., S., and Grossman, D. S., and Groth, C. J., 1979. RESERVE RECOGNITION ACCOUNTING: A PROPOSED DISCLOSURE FRAMEWORK [online]. United state, The Journal of Accountancy. Available at: http://mays.tamu.edu/research/publication/1762/ .

[11] Exxon Mobil Corporation, 2013. Annual report ended at 31rd December 2007-2011 [online]. United State of America: Exxon Mobil Corporation. Available at: http://ir.exxonmobil.com/phoenix.zhtml?c=115024\&p=irol-reportsannual.

[12] GLOBAL ENERGY DEVELOPMENT PLC, 2011.

[13] Harmon, E. F., 2008. MODERNIZATION OF OIL AND GAS REPORTING [online]. United State of America, SPE. Available at: http://www.sec.gov/rules/final/2008/33-8995.pdf.

[14] Harvey, R. C., 2012. Market value[online]. United state, Duke University. Available at: http://financial-dictionary.thefreedictionary.com/market+value. 
[15] Insites, 2007. Tips on Qualitative and Qualitative Data Collection Methods [online]. United Kingdom: insites. Available at: http://www.wmich.edu/evalctr/checklists/checklistmenu.htm [ Accessed on 31/January/2013].

[16] Investopedia, 2013. Definition of 'Market Value [online]. United Kingdom, (s.n.). Available at: http://www.investopedia.com/terms/m/marketvalue.asp .

[17] Kretzschmar L.G., and Kirchner, A.,2009. Oil price and reserve location-Effects on oil and gas sector returns [Online]. United Kingdom, University of Edinburgh. Global Finance Journal 20 (2009) 260-272. Available at: http://www.kimep.kz/files/news/Global_Finance_Journal.pdf

[18] Lundin Petroleum, 2013. Annual report ended at 31rd December 2007-2011 [online]. Sweden: Lundin Petroleum. Available at: http://www.lundin-petroleum.com/eng/financial_reports.php .

[19] Marathon Oil Corporation, 2013. Annual report ended at 31rd June 2007-2011 [online]. United Kingdom: Marathon Oil Corporation. Available at: http://www.marathonoil.com/Investor_Center/Annual_Review/

[20] MCLEOD, S., 2008. Qualitative Quantitative [online]. (n.1.). Available at : http://www.simplypsychology.org/qualitativequantitative.html\#sthash.wXhbHblO.dpbs.

[21] NEXEN'S GLOBAL PORTFOLIO, 2013. Annual report ended at 31rd December 2007-2011 [online]. United Kingdom : NEXEN'S GLOBAL PORTFOLIO. Available at: http://www.nexeninc.com/en/Investors/AnnualReports.aspx .

[22] Oil \& Gas IQ, 2013. Changes to Oil and Gas Reserves Reporting [online]. United Kingdom: (s.n). Available at: http://www.oilandgasiq.com/strategy-management-and-information/articles/changes-tooil-and-gas-reserves-reporting/.

[23] OPEC, 2013. Average prices for OPEC crude oil from 1960 to 2012 (in U.S. dollars per barrel) [online]. New York: Statista. Available at : http://www.statista.com/statistics/810/opec-crude-oilprice-development-since-1960/.

[24] Reserve Information [online]. (s.1). Society of Petroleum Engineers. Available at: http://www.spe.org/industry/docs/Estimating_and_Auditing_Standards_for_Reserves.pdf.

[25] Royal Dutch Shell plc, 2013. Annual report ended at 31rd December 2007-2011 [online]. Netherlands: Royal Dutch Shell plc. Available at: http:/www.shell.com/global/aboutshell/investor/financial-information/annual-reports-andpublications.html.

[26] SEC, 2009. Modernization of Oil and Gas Reporting; Final Rule [online]. Canada, Securities and Exchange Commission. Available at: http://www.sec.gov/rules/final/2009/33-8995fr.pdf .

[27] SPE, 2001. Standards Pertaining to the Estimating and Auditing of Oil and Gas

[28] Statoil ASA, 2013. Annual report ended at 31rd December 2007-2011 [online]. United Kingdom : Statoil ASA. Available at: http://www.statoil.com/en/Pages/default.aspx .

[29] THOMAS,R,D., 2003. A general inductive approach for qualitative data analysis [online]. University of Auckland. New Zealand. Available at http://www.fmhs.auckland.ac.nz/soph/centres/hrmas/ docs/Inductive2003.pdf.

[30] Tullow Oil plc, 2013. Annual report ended at 31rd December 2007-2011 [online]. United Kingdom : Tullow Oil plc. Available at: http://www.tullowoil.com/index.asp?pageid=353 .

[31] U.S. Energy Information Administration, 2013. Selected national average natural gas prices, 20072012 [online]. United States: U.S. Energy Information Administration. Available at : http://www.eia.gov/naturalgas/monthly/pdf/table 03.pdf.

[32] Wolski, C., Media, D., 2007. Five Factors or Events that Affect the Stock Market [online]. United state, Houston Chronicle Available at: http://smallbusiness.chron.com/five-factors-events-affectstock-market-3384.html .

[33] YAHOO FINANCE, 2013. BHP Billiton PLC. United Kingdom. Available at http://uk.finance.yahoo.com/echarts?s=BLT.L\#symbol=blt.l;range=5y;compare=;indicator=volume;c

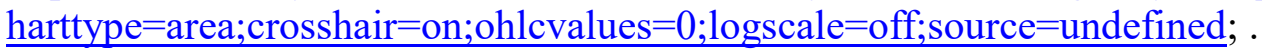

[34] YAHOO FINANCE, 2013. BP PLC. United Kingdom. Available at http://uk.finance.yahoo.com/echarts?s=BP.L .

[35] YAHOO FINANCE, 2013. Chevron Corporation. United Kingdom. Available at http://uk.finance.yahoo.com/echarts?s=CVX . 
[36] YAHOO FINANCE, 2013. Exxon Mobil Corporation. United Kingdom. Available at http://uk.finance.yahoo.com/echarts?s=XOM\#symbol=xom;range=5y;compare=mobil +corporation;i

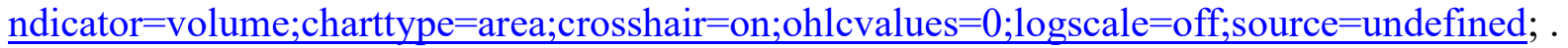

[37] YAHOO FINANCE, 2013. Lundin Petroleum. United Kingdom. Available at http://uk.finance.yahoo.com/echarts? $=$ LNDNF .

[38] YAHOO FINANCE, 2013. Marathon Oil Corporation. United Kingdom. Available at http://uk.finance.yahoo.com/echarts?s=MRO\#symbol=mro;range=5y;compare=;indicator=volume;c harttype $=$ area; crosshair $=$ on; ohlcvalues $=0 ; \operatorname{logscale}=$ off; source $=$ undefined; .

[39] YAHOO FINANCE, 2013. NEXEN'S GLOBAL PORTFOLIO [online]. United Kingdom. Available at

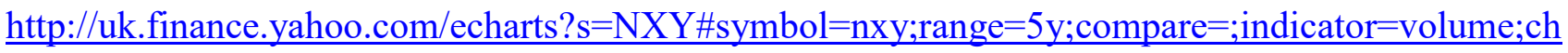
arttype $=$ area; crosshair $=$ on; ohlcvalues $=0 ; \operatorname{logscale}=$ off; source $=$ undefined; .

[40] YAHOO FINANCE, 2013. Royal Dutch Shell plc. United Kingdom. Available at: http://uk.finance.yahoo.com/echarts?s=RDSB.L .

[41] YAHOO FINANCE, 2013. Statoil ASA [online]. United Kingdom. Available at http://uk.finance.yahoo.com/echarts? $\mathrm{s}=\mathrm{DNQA} . \mathrm{DE} \#$ symbol=dnqa.de;range $=5 \mathrm{y} ;$ compare $=$;indicator $=$ volume; charttype $=$ area; crosshair $=$ on; ohlcvalues $=0 ; \operatorname{logscale}=$ off; source $=$ undefined; .

[42] YAHOO FINANCE, 2013. Tullow Oil PLC. United Kingdom. Available at http://uk.finance.yahoo.com/echarts?s=TLW.L\#symbol=tlw.1;range=5y; compare $=$;indicator=volume; charttype $=$ area; crosshair $=$ on; ohlcvalues $=0 ; \operatorname{logscale}=$ off; source $=$ undefined; .

\section{Appendixes}

\begin{tabular}{|c|c|c|}
\hline \multicolumn{3}{|c|}{ Appendix (1) } \\
\hline years & reserve & market value \\
\hline 2007 & 1566912.36 & 2255345573 \\
\hline 2008 & 2333777.1 & 2273489089 \\
\hline 2009 & 1735371.84 & 1831374216 \\
\hline 2010 & 1694860.68 & 2292294416 \\
\hline 2011 & 2550535.64 & 2389080911 \\
\hline & Correlation & 0.461980505 \\
\hline & & $46 \%$ \\
\hline
\end{tabular}

\section{Appendix (2)}

\begin{tabular}{|c|r|r|r|r|r|r|r|}
\hline \multicolumn{2}{|c|}{ BP PLC } & \multicolumn{2}{c|}{ BHP Billiton PLC } & \multicolumn{2}{c|}{ Chevron Corporation } & \multicolumn{2}{c|}{ Marathon Oil Corporation } \\
\hline $\begin{array}{c}\text { Reserve } \\
\text { value }\end{array}$ & Market Value & $\begin{array}{c}\text { Reserve } \\
\text { value }\end{array}$ & $\begin{array}{c}\text { Market } \\
\text { Value }\end{array}$ & $\begin{array}{c}\text { Reserve } \\
\text { value }\end{array}$ & $\begin{array}{c}\text { Market } \\
\text { Value }\end{array}$ & $\begin{array}{c}\text { Reserve } \\
\text { value }\end{array}$ & $\begin{array}{c}\text { Market } \\
\text { Value }\end{array}$ \\
\hline 339834.74 & 9877453650 & 68559.504 & 4794792744 & 627661.48 & 142265746.3 & 20662.5 & 41225.85 \\
\hline 482608.71 & 10264093156 & 93454.114 & 3833065878 & 875542.75 & 177155497.3 & 25655.43 & 34568.69 \\
\hline 805326.56 & 8408673339 & 101594.419 & 3632264988 & 475792.25 & 121028663.3 & 9997.08 & 23639.06 \\
\hline 1006107.4 & 10877476101 & 128166.07 & 4011555558 & 555978.26 & 144116529.9 & 11724.16 & 24763.2 \\
\hline 1280740.07 & 9390842329 & 226688.227 & 4184786415 & 724530.33 & 200830597.9 & 10530.7 & 19850.6 \\
\hline & -0.1178489 & & - & & 0.796223584 & & 0.848357191 \\
\hline & $-12 \%$ & & 0.106132154 & & & & \\
\hline
\end{tabular}

\section{Appendix (3)}




\begin{tabular}{|r|r|r|r|r|r|}
\hline \multicolumn{1}{|c|}{ Reserve value } & \multicolumn{1}{c|}{ Market Value } & \multicolumn{1}{c|}{ Reserve value } & \multicolumn{1}{c|}{ Market Value } & \multicolumn{1}{l|}{ Reserve value } & \multicolumn{1}{l|}{ Market Value } \\
\hline 332585.29 & 4503275520 & 1191186.46 & 353597.44 & 12740850.12 & 2454983512 \\
\hline 453180.19 & 4801234048 & 1654820.23 & 444754.88 & 19299918.73 & 2660911555 \\
\hline 526142.67 & 4000579072 & 958665.55 & 320963.3 & 14221000.93 & 1179448252 \\
\hline 686742.28 & 4652964608 & 1256347.94 & 323635 & 12949827.62 & 1746282816 \\
\hline 838182.98 & 5667457689 & 1615097.78 & 403999.56 & 20322644.23 & 2683801116 \\
\hline & 0.664115304 & & 0.910900435 & & 0.621666697 \\
\hline & $66 \%$ & & $91 \%$ & & $62 \%$ \\
\hline
\end{tabular}

\section{Appendix (4)}

\begin{tabular}{|r|r|r|r|r|r|}
\hline \multicolumn{2}{|c|}{ Tullow Oil plc } & \multicolumn{2}{c|}{ Statoil ASA } & \multicolumn{2}{c|}{$\begin{array}{c}\text { NEXEN'S GLOBAL } \\
\text { PORTFOLIO }\end{array}$} \\
\hline Reserve value & Market Value & Reserve value & Market Value & Reserve value & \multicolumn{1}{c|}{ Market Value } \\
\hline 29952.135 & 264276772.5 & 291930.31 & 499820417.3 & 25901.08 & 16192548.25 \\
\hline 65383.597 & 463918737 & 358416.58 & 517836272.8 & 28790.63 & 16196419.82 \\
\hline 44614.187 & 587952803 & 192522.5 & 376260346 & 18062.29 & 7190095 \\
\hline 94901.92 & 1056112604 & 237022.94 & 422495727.5 & 21788.22 & 11591817.3 \\
\hline 156186.416 & 1280454725 & 304210.21 & 467774514.9 & 26545.46 & 14437873.55 \\
\hline & 0.93401888 & & 0.953724422 & & 0.959981851 \\
\hline & $93 \%$ & & $95 \%$ & & $96 \%$ \\
\hline
\end{tabular}

\begin{tabular}{|c|c|c|c|c|c|}
\hline \multicolumn{6}{|c|}{ Appendix (5) } \\
\hline companies & 2007 & 2008 & 2009 & 2010 & 2011 \\
\hline \multicolumn{6}{|l|}{ BP PLC } \\
\hline oil reserve & 4581 & 4688 & 10511 & 10530 & 10387 \\
\hline \multirow[t]{2}{*}{ oil price } & 69.04 & 94.1 & 60.86 & 77.38 & 107.46 \\
\hline & 316272.24 & 441140.8 & 639699.46 & 814811.4 & 1116187.02 \\
\hline Gas reserve & 3770 & 5203 & 45130 & 42700 & 41659 \\
\hline \multirow[t]{2}{*}{ gas price } & 6.25 & 7.97 & 3.67 & 4.48 & 3.95 \\
\hline & 23562.5 & 41467.91 & 165627.1 & 191296 & 164553.05 \\
\hline Total Reserve & 339834.74 & 482608.71 & 805326.56 & 1006107.4 & 1280740.07 \\
\hline share price & 522 & 548 & 448.25 & 578.7 & 494.75 \\
\hline number of shares & 18922325 & 18730097 & 18758892 & 18796399 & 18980985 \\
\hline Market value & 9877453650 & 10264093156 & 8408673339 & 10877476101 & 9390842329 \\
\hline \multicolumn{6}{|l|}{$\begin{array}{l}\text { BHP Billiton } \\
\text { PLC }\end{array}$} \\
\hline oil reserve & 565.1 & 598.6 & 1381.4 & 1394.3 & 1833.7 \\
\hline \multirow[t]{2}{*}{ oil price } & 69.04 & 94.1 & 60.86 & 77.38 & 107.46 \\
\hline & 39014.504 & 56328.26 & 84072.004 & 107890.934 & 197049.402 \\
\hline gas reserve & 4727.2 & 4658.2 & 4774.5 & 4525.7 & 7503.5 \\
\hline \multirow[t]{2}{*}{ gas price } & 6.25 & 7.97 & 3.67 & 4.48 & 3.95 \\
\hline & 29545 & 37125.854 & 17522.415 & 20275.136 & 29638.825 \\
\hline Total Reserve & 68559.504 & 93454.114 & 101594.419 & 128166.07 & 226688.227 \\
\hline share price & 1428 & 1718 & 1628 & 1798 & 1959 \\
\hline
\end{tabular}




\begin{tabular}{|c|c|c|c|c|c|}
\hline \multicolumn{6}{|l|}{$\begin{array}{l}\text { Chevron } \\
\text { Corporation }\end{array}$} \\
\hline oil reserve & 7087 & 7350 & 6247 & 5781 & 5688 \\
\hline \multirow[t]{2}{*}{ oil price } & 69.04 & 94.1 & 60.86 & 77.38 & 107.46 \\
\hline & 489286.48 & 691635 & 380192.42 & 447333.78 & 611232.48 \\
\hline gas reserve & 22140 & 23075 & 26049 & 24251 & 28683 \\
\hline \multirow{2}{*}{ gas price } & 6.25 & 7.97 & 3.67 & 4.48 & 3.95 \\
\hline & 138375 & 183907.75 & 95599.83 & 108644.48 & 113297.85 \\
\hline Total Reserve & 627661.48 & 875542.75 & 475792.25 & 555978.26 & 724530.33 \\
\hline share price & 68.52 & 89.02 & 60.71 & 72.3 & 102.1 \\
\hline number of shares & 2076266 & 1990064 & 1993554 & 1993313 & 1966999 \\
\hline Market value & 142265746.3 & 177155497.3 & 121028663.3 & 144116529.9 & 200830597.9 \\
\hline \multicolumn{6}{|l|}{$\begin{array}{l}\text { MARATHON } \\
\text { OIL CORP }\end{array}$} \\
\hline oil reserve & 1,192 & 1,169 & 1,679 & 1,638 & 1,800 \\
\hline \multirow[t]{2}{*}{ oil price } & 69.04 & 94.1 & 60.86 & 77.38 & 107.46 \\
\hline & 82295.68 & 110002.9 & 102183.94 & 126748.44 & 193428 \\
\hline gas reserve & 3,306 & 3,219 & 2,724 & 2,617 & 2,666 \\
\hline \multirow[t]{2}{*}{ gas price } & 6.25 & 7.97 & 3.67 & 4.48 & 3.95 \\
\hline & 20662.5 & 25655.43 & 9997.08 & 11724.16 & 10530.7 \\
\hline Total Reserve & 102958.18 & 135658.33 & 112181.02 & 138472.6 & 203958.7 \\
\hline share price & 53.89 & 45.07 & 30.74 & 32.16 & 25.78 \\
\hline number of shares & 765 & 767 & 769 & 770 & 770 \\
\hline Market value & 41225.85 & 34568.69 & 23639.06 & 24763.2 & 19850.6 \\
\hline \multicolumn{6}{|l|}{$\begin{array}{l}\text { Royal Dutch } \\
\text { Shell plc }\end{array}$} \\
\hline oil reserve & 2,751 & 2,620 & 5,687 & 6,146 & 6,048 \\
\hline \multirow[t]{2}{*}{ oil price } & 69.04 & 94.1 & 60.86 & 77.38 & 107.46 \\
\hline & 189929.04 & 246542 & 346110.82 & 475577.48 & 649918.08 \\
\hline gas reserve & 22,825 & 25,927 & 49,055 & 47,135 & 47,662 \\
\hline \multirow[t]{2}{*}{ gas price } & 6.25 & 7.97 & 3.67 & 4.48 & 3.95 \\
\hline & 142656.25 & 206638.19 & 180031.85 & 211164.8 & 188264.9 \\
\hline Total Reserve & 332585.29 & 453180.19 & 526142.67 & 686742.28 & 838182.98 \\
\hline share price & 1,632 & 1,781 & 1,484 & 1,726 & 2,130 \\
\hline number of shares & $2,759,360$ & $2,695,808$ & $2,695,808$ & $2,695,808$ & $2,661,403$ \\
\hline Market value & 4503275520 & 4801234048 & 4000579072 & 4652964608 & 5667457689 \\
\hline \multicolumn{6}{|l|}{$\begin{array}{l}\text { Exxon Mobil } \\
\text { Corporation }\end{array}$} \\
\hline oil reserve & 11074 & 12006 & 11651 & 11673 & 12228 \\
\hline \multirow[t]{2}{*}{ oil price } & 69.04 & 94.1 & 60.86 & 77.38 & 107.46 \\
\hline & 764548.96 & 1129764.6 & 709079.86 & 903256.74 & 1314020.88 \\
\hline gas reserve & 68262 & 65879 & 68007 & 78815 & 76222 \\
\hline \multirow[t]{2}{*}{ gas price } & 6.25 & 7.97 & 3.67 & 4.48 & 3.95 \\
\hline & 426637.5 & 525055.63 & 249585.69 & 353091.2 & 301076.9 \\
\hline Total Reserve & 1191186.46 & 1654820.23 & 958665.55 & 1256347.94 & 1615097.78 \\
\hline share price & 71.68 & 89.38 & 67.9 & 65 & 85.34 \\
\hline number of shares & 4933 & 4976 & 4727 & 4979 & 4734 \\
\hline Market value & 353597.44 & 444754.88 & 320963.3 & 323635 & 403999.56 \\
\hline $\begin{array}{l}\text { Lundin } \\
\text { Petroleum }\end{array}$ & & & & & \\
\hline
\end{tabular}




\begin{tabular}{|c|c|c|c|c|c|}
\hline oil reserve & 169,828 & 189,056 & 221,080 & 157,081 & 183,008 \\
\hline \multirow{2}{*}{ oil price } & 69.04 & 94.1 & 60.86 & 77.38 & 107.46 \\
\hline & 11724925.12 & 17790169.6 & 13454928.8 & 12154927.78 & 19666039.68 \\
\hline gas reservew & 162548 & 189429 & 208739 & 177433 & 166229 \\
\hline \multirow[t]{2}{*}{ gas price } & 6.25 & 7.97 & 3.67 & 4.48 & 3.95 \\
\hline & 1015925 & 1509749.13 & 766072.13 & 794899.84 & 656604.55 \\
\hline Total Reserve & 12740850.12 & 19299918.73 & 14221000.93 & 12949827.62 & 20322644.23 \\
\hline share price & 7.78 & 8.37 & 3.71 & 5.493 & 8.442 \\
\hline number of shares & 315550580 & 317910580 & 317910580 & 317910580 & 317910580 \\
\hline Market value & 2454983512 & 2660911555 & 1179448252 & 1746282816 & 2683801116 \\
\hline \multicolumn{6}{|l|}{ Tullow Oil } \\
\hline oil reserve & 294 & 559.9 & 642 & $1,140.80$ & $1,371.60$ \\
\hline \multirow[t]{2}{*}{ oil price } & 69.04 & 94.1 & 60.86 & 77.38 & 107.46 \\
\hline & 20297.76 & 52686.59 & 39072.12 & 88275.104 & 147392.136 \\
\hline gas reserve & 1544.7 & 1593.1 & 1510.1 & 1479.2 & 2226.4 \\
\hline \multirow[t]{2}{*}{ gas price } & 6.25 & 7.97 & 3.67 & 4.48 & 3.95 \\
\hline & 9654.375 & 12697.007 & 5542.067 & 6626.816 & 8794.28 \\
\hline Total Reserve & 29952.135 & 65383.597 & 44614.187 & 94901.92 & 156186.416 \\
\hline share price & 367.25 & 633 & 731 & 1189 & 1415 \\
\hline number of shares & 719610 & 732889 & 804313 & 888236 & 904915 \\
\hline Market value & 264276772.5 & 463918737 & 587952803 & 1056112604 & 1280454725 \\
\hline \multicolumn{6}{|l|}{ Statoil ASA } \\
\hline oil reserve & 2389 & 2201 & 2069 & 2023 & 2181 \\
\hline \multirow[t]{2}{*}{ oil price } & 69.04 & 94.1 & 60.86 & 77.38 & 107.46 \\
\hline & 164936.56 & 207114.1 & 125919.34 & 156539.74 & 234370.26 \\
\hline gas reserve & 20319 & 18984 & 18148 & 17965 & 17681 \\
\hline \multirow[t]{2}{*}{ gas price } & 6.25 & 7.97 & 3.67 & 4.48 & 3.95 \\
\hline & 126993.75 & 151302.48 & 66603.16 & 80483.2 & 69839.95 \\
\hline Total Reserve & 291930.31 & 358416.58 & 192522.5 & 237022.94 & 304210.21 \\
\hline share price & 156.75 & 162.4 & 118 & 132.5 & 146.7 \\
\hline number of shares & 3188647 & 3188647 & 3188647 & 3188647 & 3188647 \\
\hline Market value & 499820417.3 & 517836272.8 & 376260346 & 422495727.5 & 467774514.9 \\
\hline \multicolumn{6}{|l|}{ Nexen } \\
\hline oil reserve & 327 & 262 & 272 & 255 & 231 \\
\hline \multirow[t]{2}{*}{ oil price } & 69.04 & 94.1 & 60.86 & 77.38 & 107.46 \\
\hline & 22576.08 & 24654.2 & 16553.92 & 19731.9 & 24823.26 \\
\hline gas reserve & 532 & 519 & 411 & 459 & 436 \\
\hline \multirow[t]{3}{*}{ gas price } & 6.25 & 7.97 & 3.67 & 4.48 & 3.95 \\
\hline & 3325 & 4136.43 & 1508.37 & 2056.32 & 1722.2 \\
\hline & 25901.08 & 28790.63 & 18062.29 & 21788.22 & 26545.46 \\
\hline Total Reserve & 30.65 & 31.18 & 13.75 & 22.05 & 27.35 \\
\hline number of shares & 528,305 & 519,449 & 522,916 & 525,706 & 527,893 \\
\hline Market value & 16192548.25 & 16196419.82 & 7190095 & 11591817.3 & 14437873.55 \\
\hline
\end{tabular}

